\title{
Natural Disasters in Medieval Greek Apocalypses
}

\author{
András Kraft \\ Princeton University, Princeton, NJ, USA \\ akraft@princeton.edu
}

\begin{abstract}
Natural calamities form a standard theme in Byzantine apocalypses. This paper discusses their function and meaning by surveying more than a dozen medieval Greek apocalyptic narratives from the sixth to the fifteenth century. It is shown that natural disasters were understood as ambiguous epiphenomena, whose ultimate meaning revolved around human agency and intentionality. Furthermore, it is argued that Byzantine apocalypses offered an intellectual strategy for coping with natural calamities by placing them into an eschatological context. This eschatologization restored epistemological control of the - seemingly uncontrollable - phenomena. Finally, it is suggested that the understanding of natural disasters as anthropogenic events is not only characteristic of medieval Greek apocalypticism but also of modern-day environmental alarmism. The paper closes with a preliminary comparison of these two hermeneutic paradigms.
\end{abstract}

\section{Keywords}

apocalyptic literature - ambiguity - anthropocentricism - environmental alarmism

Christian apocalyptic literature contains vivid descriptions of natural catastrophes that were expected to precede the end of the world. Canonical biblical books and apocryphal medieval compositions advance various stock motifs of natural calamities, including earthquakes and fires, floods and droughts, solar eclipses and meteor showers. The biblical sources are, first of all, the Book of Isaiah, the Synoptic Apocalypse (Mt 24, Mk 13, Lk 21), and the Book of Revelation. Isaiah speaks about earthquakes (Is 13:13, 24:18-20, 29:6), famines (Is 8:21, 51:19), and eclipses (Is 13:10). Similarly, the Synoptic Apocalypse predicts that "there shall be famines, and pestilences, and earthquakes, in divers places" 
(Mt 24:7, KJV; cf. Mk 13:8, Lk 21:11) and that "the sun [shall] be darkened, and the moon shall not give her light, and the stars shall fall from heaven" (Mt 24:29, KJV; cf. Mk 13:24-25, Lk 21:25). The Book of Revelation also makes reference to earthquakes ( $\operatorname{Rv} 6: 12,8: 5,11: 13,11: 19,16: 18)$ and meteor showers (Rv 6:13, 8:10, 9:1). These and other biblical passages have shaped the Christian vocabulary and imagery of natural disasters. Moreover, they determined the medieval horizon of expectations with regard to anticipating, interpreting, and coping with catastrophic changes in nature. The eschatological significance of natural disasters was expressed in various literary genres, including hagiography, historiography, and especially in revelatory texts. Disasters formed part and parcel of the apocalyptic tradition.

Although natural calamities appear frequently in medieval Greek apocalypses, they are not a dominant theme since these texts are not much concerned with changes in the physical world. Most attention is given to human agents, be they individual (e.g., emperors, the Antichrist) or collective agents (e.g., the Ishmaelites, the blond nations, Gog/Magog). Events in nature play a subordinate role. This is a function of the literary genre of apocalypses, which constructs binary oppositions between good and evil protagonists. The mechanics of these oppositions are driven by personal agency. This is so much the case that even abstract entities such as cities, regions, and the earth itself are personified. ${ }^{1}$ Although the end-time struggle takes place in the cosmos, the cosmos itself is little more than a passive bystander; it merely mirrors the real cosmic forces, which are willful personal agents arbitrating between good and evil.

Despite its subordinate significance, natural disasters form a standard theme in medieval Greek apocalyptica. The aim of this paper is to survey these references and to establish how disasters in nature were understood in a dozen or so Byzantine apocalyptic narratives that range from the early sixth to the late fifteenth century. ${ }^{2}$ It will be shown that cataclysms in the natural environment were understood, on the one hand, as inherently ambiguous events and, on the other, as epiphenomena of divine or satanic powers. Accordingly, nature was

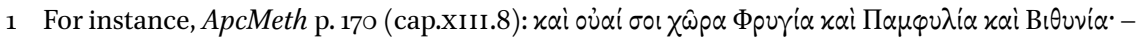
And woe to you, land of Phrygia, and Pamphylia, and Bithynia! VisioDan p. 210 (§III.7-8):

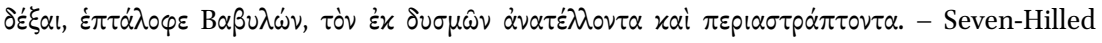
Babylon [i.e., Constantinople], receive him, who rises from the West and shines about.

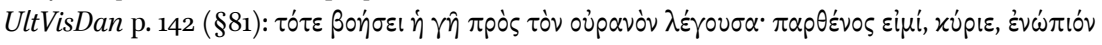
бov. - Then the earth will shout to heaven and say: 'Lord, I am a virgin before you.' (translations mine).

2 See the Appendix for an overview of the surveyed sources. 
denied any autonomous causal efficacy. Finally, it will be suggested that the latter assumption enjoys a revival in contemporary environmental alarmism.

Before surveying the Byzantine source material, I should define my terminology. Natural disasters are understood here as phenomena that occur in the physical environment and that disrupt the normal functioning of society. As will become apparent, Byzantine apocalyptists did not differentiate 'natural' catastrophes from either man-made or supernatural (i.e., miraculous, paranormal) calamities. Thus, we need to suspend our contemporary assumption that locates the causality of natural disasters in the orderly and autonomous operations of the physical world. Apocalyptists saw nature much like a theater stage, which passively supports the protagonists' performance with its setting and décor. Under apocalypse, I understand a literary genre of narrative texts that predict (or prescribe) how the socio-political status quo will be transformed in the period that leads up to the Second Coming. The narratives examined in this study are, above all, concerned with the historical developments that precede the end of the world. ${ }^{3}$ Apart from eschatological relevance, medieval Greek apocalypses are characterized by typological hermeneutics. Typology is an exegetical method and a theory of history; it places historical events into the narrative framework of salvation history by assigning reciprocal correspondences between specific events in such a way that previous events (types) are presented to prefigure subsequent events (antitypes), which, in turn, fulfill their earlier adumbrations. As a result, much of the material in Byzantine apocalypses is derived from the historiographical tradition, first and foremost, from the Scriptures but also from chronicles and histories. Both eschatological relevance and typological exegesis are crucial aspects of Byzantine apocalypses. ${ }^{4}$

3 Only apocalyptic texts written in prose have been selected. Versified prophecies have been excluded because they often use natural objects (plants and animals) in a metaphoric way that makes it difficult to discern whether actual natural occurrences are described or not. Pertinent material from exegetical literature has been omitted as well, such as Ps-Hippolytus,

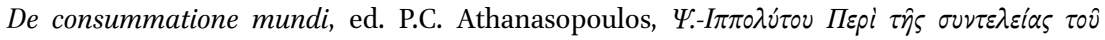

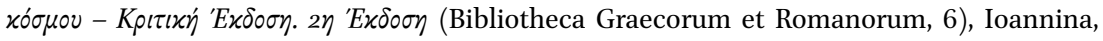
2016, pp. 75-116, esp. pp. 80, 96, 106 (§VIII, §XXVII, §XxXVII). Only historical apocalypses have been considered here, as otherworldly journeys (also called moral apocalypses or Tour-of-Hell apocalypses) are generally disinterested in the physical world; their focus lies with the transcendental realm of post-mortem existence. The Apocryphal Apocalypse of John is an exceptional text: it is neither a historical apocalypse (as it is not interested in political events) nor a heavenly journey (as it does not discuss the underworld or the afterlife). It has been included here because it prognosticates natural changes at the eschaton.

4 The two characteristics of eschatological relevance and typological exegesis hardly make for a precise definition. My reluctance to define clearly the genre is intentional, as I believe that no strict definition ought to be given. This stands in contrast to the definitory approach of the sBL Apocalypse Group (1979), epitomized by the classical definition by J.J. Collins, "Introduction: Towards the Morphology of a Genre," Semeia, 14 (1979), pp. 1-20, at p. 9. As 
Although Byzantine prophecies do not assign primary importance to natural calamities, one can hardly find a Byzantine end-time narrative that does not integrate references to disasters like earthquakes, droughts, or celestial aberrations. Heavenly anomalies most often amount to either color changes in the luminaries or to celestial apparitions. ${ }^{5}$ In particular, it is the Antichrist's prerogative to cause darkness (presumably through a solar eclipse), which signifies the typological emulation of the darkness at Christ's crucifixion (Mt 27:45, Mk 15:33, Lk 23:44-45). ${ }^{6}$ Some apocalypses voice the expectation that stars will fall from heaven. ${ }^{7}$

Other natural disasters include devastation through animals (locusts, serpents, birds $),{ }^{8}$ drought, ${ }^{9}$ famine, ${ }^{10}$ disease, ${ }^{11}$ and flooding. ${ }^{12}$ The latter motif

argued in A. Kraft, "Byzantine Apocalyptic Literature," in: The Cambridge Companion to Apocalyptic Literature, ed. C. McAllister, Cambridge, 2020 , pp. 172-189, at pp. 174-178, I favor a prototype approach that determines genre membership not by detecting essential, indispensable constituents but by identifying prototypical samples and by discerning the resemblance between a given text to these samples. Resemblance to prototypes allows for varying degrees of genre membership and can accommodate the generic fuzziness of Byzantine apocalypses. My approach draws upon C.A. Newsom, "Spying out the Land: A Report from Genology," in: Seeking Out the Wisdom of the Ancients: Essays Offered to Honor Michael V. Fox on the Occasion of His Sixty-Fifth Birthday, ed. R.L. Troxel, K.G. Friebel, and D.R. Magary, Winona Lake, IN, 2005, pp. 437-450 and concurs with the proposition by D.E. Aune, The New Testament in Its Literary Environment, Philadelphia, PA, 1987, p. 13, who points outs that "a literary genre may be defined as a group of texts that exhibit a coherent and recurring configuration of literary features involving form [...], content, and function." For an overview of how the apocalyptic genre has been variously defined, see A.Y. Collins, "Apocalypse Now: The State of Apocalyptic Studies Near the End of the First Decade of the Twenty-First Century," Harvard Theological Review, 104/4, (2011), pp. $447-457$.

5 Celestial color changes: SibTibGr 1l.210-211; ApcMeth pp. 19o, 192 (cap.xiv.8); ApcIoh p. 75 (§7); Ps-Chrys p. 234 (§vi.6); ApcAndr ll.4o61-63; VisDanSanHom ll.686-687, l.81o. Other celestial signs: ApcIoh pp. 71-72 (§2), pp. 86-87 (\$19); NarrMend 1l.118-128; ApcLeonConst l.5o6 (§19); VisDanSanHom 1l.724-725, ll.8o8-8o9; ExpugCon p. 152, l.32, p. 155, l.23.

6 Solar darkness: SibTibGr ll.210-211; ApcMeth pp. 19o, 192 (cap.XIv.8); Ps-Chrys p. 234 (§vi.6); ApcIoh p. 86 (\$19); VisDanSanHom ll.108, ll.686-687, l.81o.

$7 \quad$ Falling stars: ApcIoh pp. 86-87 (\$19); VisDanSanHom 1.8o9.

8 Animal infestation: SibTibGr ll.115-117; ApcAndr ll.3903-05; UltVisDan p. 126 (§§12-14).

9 Drought: SibTibGr 1l.211-214; DiegDan p. 17 (§XII.22-24); ApcIoh p. 75 ( $\$ 7$ ); ApcLeonConst ll.438-440 (\$16); VisDanSanHom ll.713-715.

10 Famine: ApcMeth p. 146 (cap.XI.13), p. 164 (cap.XIII.2); DiegDan p. 16 (§XII.6-9); ApcIoh p. 73 (§5); ApcLeonConst ll.33-34 (§1), 1.435 (§16), ll.440-441 (§16), ll.5०5-509 (§19); UltVisDan p. 140 ( $\$ 76)$; VisDanSanHom l.125, ll.710-715.

11 Plague: ApcMeth p. 146 (cap.XI.13), p. 164 (cap.XIII.2); DiegDan p. 12 (§I.1), p. 16 (§XII.10), p. 17 (§XII.21-25); ApcLeonConst l.507 (§19), l.514 (§19); VisioDan p. 214 (§v.3); ExpugCon p. 153 , l.7.

12 Inundation of cities: SibTibGr ll.137-138; DiegDan p. 15 (§IX.3-8); ApcAndr ll.3992-99, ll.404off; UltVisDan pp. 138, 140 (§§69-73); VisDanSanHom ll.393-399. 
is of particular importance. Flooding usually involves the submergence of Constantinople. The wording of Byzantine apocalypses leaves no doubt that the Eastern Romans applied the New Testament motif of the submergence of Babylon (Rv 18:21) to the imperial capital. The identification of Constantinople with Babylon (Rv 17-18) had been seriously considered at least since the early seventh century, as testified by Andrew of Caesarea. ${ }^{13}$ In the tenth century, Arethas outright dismisses any alternative interpretation..$^{14}$ It is well known that the Queen of Cities was commonly viewed as the New Jerusalem as well as the New Rome. While the former conveyed the positive image of the holy city of the elect nation, the latter carried favorable as well as pejorative connotations. On the one hand, Rome signified legitimate governance and eternal rule. On the other, it stood for moral decadence and impiety. The apocalyptic tradition in Byzantium interiorized this ambivalence: Constantinople was both 'Roma aeterna' and 'Roma tyrannica'; it was the heavenly Jerusalem and the demonic Babylon. ${ }^{15}$ Constantinople's ultimate destruction well illustrates the inherent ambivalence that apocalypses endorse. Moreover, it shows that the Byzantines did not neglect the Book of Revelation as much as has been assumed in scholarship. ${ }^{16}$

13 Andreas Caesariensis, Commentarius in Apocalypsin, ed. J. Schmid, Studien zur Geschichte des griechischen Apokalypse-Textes. 1. Teil. Der Apokalypse-Kommentar des Andreas von Kaisareia. Text (Münchner theologische Studien, 1. Ergänzungsband), Munich, 1955, 181 (cap.53) (= comm. on $\mathrm{Rv}$ 17:1-3), where it is said that the Whore of Babylon (Rv 17-18) personifies either (i) Rome, or (ii) the earthly kingdom in general, or (iii) Constantinople,

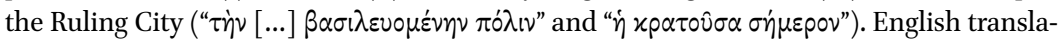
tion in E.S. Constantinou, Andrew of Caesarea: Commentary on the Apocalypse (Fathers of the Church, 123), Washington, DC, 2011, p. 181. For a historical survey on the identification of the Seven-Hilled City with Constantinople, see W. Brandes, "Sieben Hügel: Die imaginäre Topographie Konstantinopels zwischen apokalyptischem Denken und moderner Wissenschaft," Rechtsgeschichte, 2 (2003), pp. 58-71.

14 Arethas, Commentarius in Apocalypsin, ed. J.A. Cramer, Catenae graecorum Patrum in Novum Testamentum, 8 vols., Oxford, 1844, VIII, p. 424 (cap.52) (= comm. on Rv 16:19-21).

15 On the duplex association of Constantinople with Jerusalem and Babylon, see further M.-H. Congourdeau, "Jérusalem et Constantinople dans la littérature apocalyptique," in: Le sacré et son inscription dans l'espace à Byzance et en Occident: Études comparées (Byzantina Sorbonensia, 18), ed. M. Kaplan, Paris, 2001, pp. 125-136.

16 See J. Schmid, Studien zur Geschichte des griechischen Apokalypse-Textes. 2. Teil: Die alten Stämme (Münchner theologische Studien, 1. Ergänzungsband), Munich, 1955, pp. 31-43, J. Meyendorff, Byzantine Theology. Historical Trends and Doctrinal Themes, New York, NY, 1974, pp. 7-8, and B.M. Metzger, The Canon of the New Testament. Its Origin, Development, and Significance, Oxford, 1987, pp. 209-217. The Byzantine reception history of Revelation requires further research. A recent contribution in reassessing its importance has been made by S.J. Shoemaker, "The Afterlife of the Apocalypse of John in Byzantium," in: The New Testament in Byzantium (Dumbarton Oaks Byzantine symposia and colloquia), ed. 
Not only water but also fire preoccupied the Byzantine curiosity about the end times. Some prophecies predict large-scale conflagrations, ${ }^{17}$ while others foretell how fire will ascend from the sea or descend from the heaven. ${ }^{18}$ Still other accounts anticipate vulcano eruptions and violent thunderstorms and lightnings. ${ }^{19}$

It is noteworthy that references to natural disasters are not limited to any single moment in the end-time narrative. Although they tend to accumulate around the Antichrist motif, towards the end of the narratives, calamities are also mentioned beforehand; they are dispersed throughout the discourses. When reading Byzantine apocalypses synoptically, a particular pattern emerges. Descriptions of catastrophe are often juxtaposed to wonderous or miraculous accounts. Wonders interrupt the (all too often) gloomy narratives by conveying a message of hope, which is a standard literary device of the apocalyptic genre. It is well exemplified in the Book of Revelation, where sequences of afflictions are repeatedly broken up by interludes of triumph and hope ( $\mathrm{Rv} 7, \mathrm{Rv} 11)$. In a like manner, Byzantine prophecies present alternating cycles of disasters and wonders. The standard narrative sequence (i) begins with a period of great distress at the hand of foreign invaders and natural afflictions, (ii) changes over to a period of eschatological bliss with a superabundance of sustenance, ${ }^{20}$ (iii) before transitioning into the dramatic climax that often contains the most severe natural calamities. Finally, (iv) the ultimate relief, which comes with the Last Judgment, is evoked. The alteration between disaster and wonder, catastrophe and miracle, is, at times, so swift that they are mentioned in the same breath. For instance, the Byzantine Apocryphal Apocalypse of John relates a vision given to John the Apostle that reads as follows:

And I heard a voice that told me: "Listen, righteous John, at that time there will be corn and wine in abundance, such as has not happened on the earth nor will happen until those times will come. Then an ear of corn yields a pint of grain, a branch of a vine a thousand bunches of

D. Krueger and R.S. Nelson, Washington, DC, 2016, pp. 301-316, who focuses on the four Byzantine commentaries on Revelation.

17 Widespread/global conflagration: SibTibGr ll.221-223; ApcIoh p. 81 (§14); UltVisDan p. $142(\S 80)$.

18 Fire from the sea: UltVisDan p. $126(\S 16)$. Fire from heaven: ApcAndr l.39o2.

19 Vulcanic eruption: ApcLeonConst l.531 (\$19). Tempest: VisioDan p. 214 (§v.3); ApcAndr ll.3871-76, ll.3898-99, ll.4089-91.

20 Superabundant food: SibTibGr ll.206-207; DiegDan p. 14 (§vi.18), p. 16 (§XI.29-37); AnonymVatic p. 50, l.11; ApcIoh p. 73 (§5); VisioDan p. 210 (§III.15), p. 212 (§III.22); UltVisDan p. 136 (\$57); VisDanSanHom ll.708-710; ExpugCon p. 155, 1l. 4-5; VisDanSepCol pp. 194, 196 (§II.16-19). 
grapes, and a bunch of grapes half a jar of wine. And in the following year there will not be found anywhere on the face of the earth either a pint of grain or a half-jar of wine."21

Natural abundance and scarcity are juxtaposed in order to convey a sense of surprise, arbitrariness, and unpredictability. The swiftness of the transition also exposes the ephemeral and deceptive character of eschatological occurrences. Natural phenomena at the eschaton are inherently ambiguous events; their meaning is polysemous. Given the dualistic rationale (or metanarrative) of the apocalyptic genre, the range of possible meanings is usually limited to the binary opposition of positive appraisal and negative rejection. Divine and truthful phenomena demand appraisal, while demonic and spurious occurrences in nature call for defiance. A good case in point are earthquakes. Earthquakes can amount to natural disasters, but they can also accompany miraculous events.

Seen within the biblical framework in which Byzantine apocalypses were written, earthquakes denote "the beginning of the birth pangs" ( $\dot{\alpha} p x \dot{\eta} \omega \dot{\delta} i \nu \omega \nu$, Mt 24:8) of the eschaton. ${ }^{22}$ Therefore, it is no surprise to find earthquakes as a stock motif in medieval Greek prophecies. Their function is often confined to

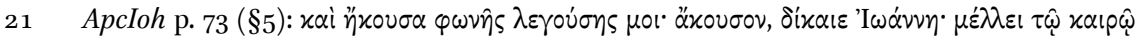

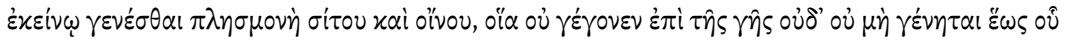

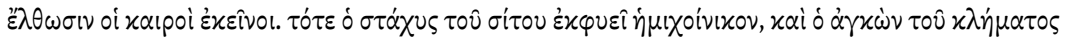

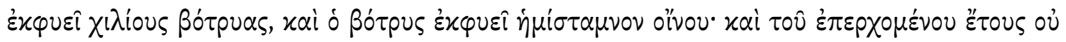

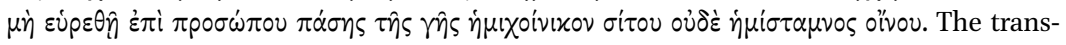
lation is by J.M. Court, The Book of Revelation and the Johannine Apocalyptic Tradition (Journal for the Study of the New Testament, Supplement Series, 190), Sheffield, 200o, p. 33, slightly changed. The same notion is repeated in the Byzantine Apocalypse of Daniel (DiegDan p. 16 (§XI.29-XII.8)) as well as in the Visions of Daniel \& Other Holy Men, see

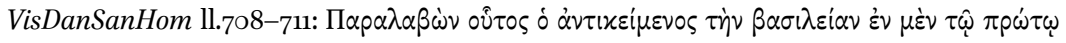

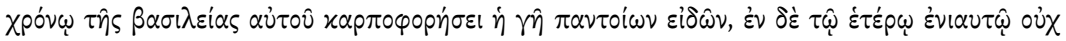

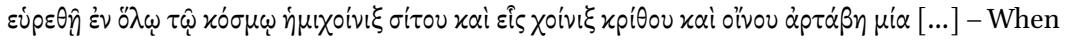
this opposer [i.e., the Antichrist] has taken hold of the empire, the earth will bear all sorts of fruits in the first year of his reign, but in the second year there will not be found anywhere in the whole world a pint [i.e., a half choenix or half of a man's daily ration] of grain, or two pints of barley, or a single volume of wine [...] (translation mine). On the notion of eschatological abundance, see further J.-M. Rosenstiehl, "Armenian Witnesses of Three Eschatological Motifs," in: The Armenian Apocalyptic Tradition: A Comparative Perspective. Essays Presented in Honor of Professor Robert W. Thomson on the Occasion of His Eightieth Birthday (Studia in Veteris Testamenti Pseudepigrapha, 25), ed. K.B. Bardakjian and S. La Porta, Leiden/Boston, MA, 2014, pp. 254-282, at pp. 263-274.

22 Earthquakes are named as signs of the end in the Synoptic Apocalypse (Mt 24:7, Mk 13:8, Lk 21:11) as well as in the Book of Revelation ( $\operatorname{Rv} 6: 12,8: 5,11: 13,11: 19,16: 18)$. 
evoking images of havoc and destruction. ${ }^{23}$ Yet, earthquakes also held another significance. They were believed to accompany divine interventions such as theophanies, the final resurrection, or the announcement of the messianic emperor. ${ }^{24}$ The pseudonymous author of the (probably thirteenth-century) Apocalypse of Leo of Constantinople refers to earthquakes not only to signify widespread destruction but also to convey a sense of awe and wonder visà-vis the Godhead. ${ }^{25}$ Elsewhere in the apocalypse, the earthquake motif is employed to explicate the resurrection of the dead. ${ }^{26}$ In both cases, seismic tremors visualize the frightful and horrific nature of a salvific event. Another notable occasion when earthquakes were expected is the appearance of the savior-emperor. ${ }^{27}$ For instance, the Vision of Daniel on the Seven Hills (probably composed in the early 1470s) depicts an earthquake that announces

23 Earthquakes as signs of the end: SibTibGr l.137; DiegDan p. 12 (§I.1); VisioDan p. 212 (§IV.5), p. 214 (§v.3); ApcIoh p. 77 (§9); ApcAndr l.3899; UltVisDan p. 138 (§69), p. 140 (§76); ApcLeonConst l.26 (§1), l.507 (§19), l.529 (§19); VisDanSanHom 1l.683, 721.

24 Earthquakes as signs of divine intervention: DiegDan p. 13 (§v.3); ApcLeonConst 1l.622-624 (§22), l.643 (§23), ll.788-789 (§29); VisDanSanHom 1l.8o5-8o6; VisDanSepCol p. 194 (§II.5).

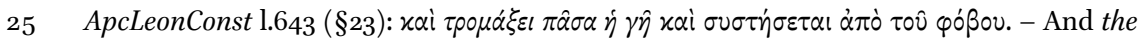
whole earth will tremble and contract by the fear [of God]. (translation and italics mine) Cf. Ps 17:8 (LXX). Old Testament texts often associate earthquakes with divine intervention. Examples can be found in R. Bauckham, "The Eschatological Earthquake in the Apocalypse of John," Novum Testamentum, 19/3 (1977), pp. 224-233, at pp. 224-226.

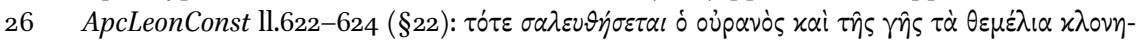

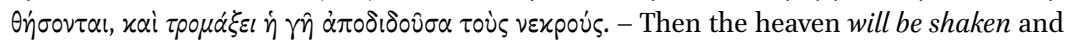
the foundations of the earth will be thrown into confusion and the earth will tremble giv-

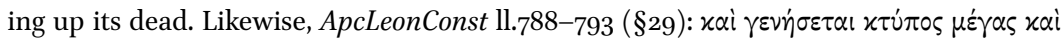

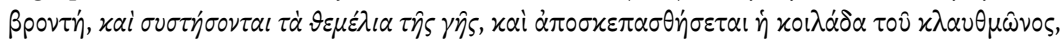

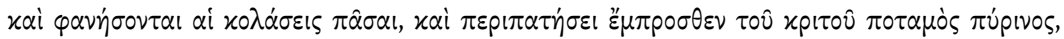

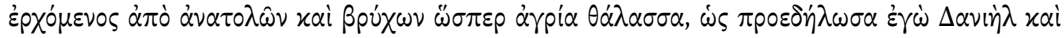

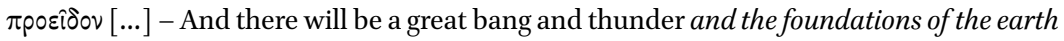
will contract, and the valley of tears will be uncovered, and all punishments will appear, and a fiery river will coil before the Judge, which comes from the East and gnashes like a stormy sea, as I, Daniel, predicted and foresaw [...] (translations and italics mine). The motif can also be found in VisDanSanHom $11.805^{-806 .}$

27 On the use of the savior-emperor (or last Roman emperor) topos in Byzantium, see A. Kraft, "The Last Roman Emperor Topos in the Byzantine Apocalyptic Tradition," Byzantion, 82 (2012), pp. 213-257 and the literature cited therein. For a comprehensive survey of the topos in the Latin West, see H. Möhring, Der Weltkaiser der Endzeit. Entstehung, Wandel und Wirkung einer tausendjährigen Weissagung (Mittelalter-Forschungen, 3), Stuttgart, 2000 . 
the eschatological emperor who would liberate Orthodox Christians from the Muslims. ${ }^{28}$

Eschatological earthquakes were recognized by the Byzantines to be an ambivalent sign. Their open-endedness is hinted at by Andrew of Caesarea, who explains that: "We find in many places of the Scriptures an earthquake as a change of events. For 'once more I shall shake' [Heb 12:26] signifies the change of the things being shaken, as the Apostle says." ${ }^{29}$ Andrew does not specify what kind of change the earthquake signifies. Although the context suggests a positive change, it is left inexplicit. This minimalist explanation reflects the prevalent ambivalence that underlies the apocalyptic genre. It was the prerogative of the apocalyptist to offer guidance in matters of proper interpretation. Apocalyptic narratives profess to provide interpretative service concerning the equivocation of eschatological events, which include natural disasters. Apocalypses, after all, are meant to reveal.

In sum, Byzantine apocalypses portray natural anomalies as ambiguous epiphenomena. They are ambiguous because their ultimate meaning and purpose is not apparent. Natural disasters can express divine retributive punishments just as well as redemptive acts of grace. Their real significance could only be discerned by inspired explication. Moreover, they are mere epiphenomena: the real causes of natural disasters do not lie in nature but in divine (or satanic) agency, which correlate with the intentional acts of mankind's (mis)conduct. The focal point of anything that happens at the end times, including natural anomalies and calamities, rests with people's intentionality. In other words, it solely depends on people's previous or anticipated behavior whether the earth shakes or the sun darkens, whether waters inundate cities or droughts hit the countryside, whether crops are abundant or failing. The function, purpose, and meaning of eschatological changes in nature is solely aimed at enticing either through reward or reproach - mankind to act properly.

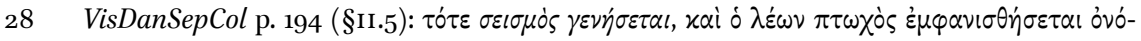

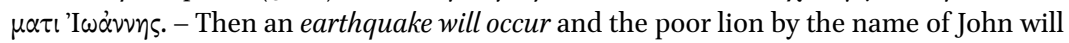
appear. (translation and italics mine) The motif can also be found in DiegDan p. 13 (§v.3). Andreas Caesariensis, Commentarius in Apocalypsin, ed. J. Schmid, p. 69 (cap.18) (=

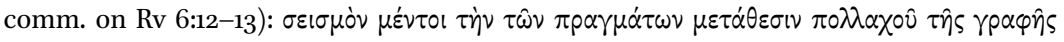

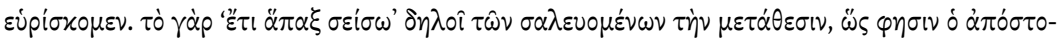
$\lambda$ os. Translation by Constantinou, Andrew of Caesarea, p. 98, modified. The same argument is repeated in Andreas Caesariensis, Commentarius in Apocalypsin, ed. J. Schmid,

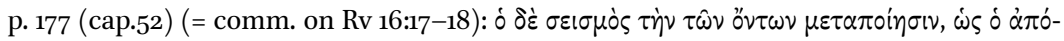

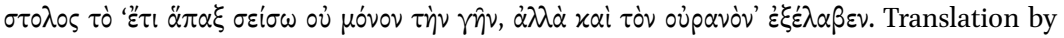
Constantinou, Andrew of Caesarea, p. 178, modified: The earthquake is an alteration of all beings, as the Apostle understood that 'once more I shall shake not only the earth but also the heaven.' 
The Eastern Romans designed various intellectual strategies that helped them to cope with the whims of nature. One such strategy was the eschatologization of the respective affliction. When placed into an eschatological context, natural disasters were assigned a final purpose and a proximate cause. The purpose was to punish or reward mankind for their actions, while the cause was the voluntary personal agency of divine or demonic powers. That is, the moral conduct of mankind was the ultimate cause that agitated divine and demonic powers (functioning as proximate causes) to effect natural disasters. By accepting causal efficacy and moral responsibility for natural anomalies, the Easter Romans gained epistemological access and, concomitantly, partial control of the - seemingly uncontrollable - phenomena. Eschatologization functioned as an epistemological and cognitive method of disaster management.

The modern reader of Byzantine apocalypses may wonder whether the hermeneutic model of eschatologization has been rendered obsolete. To answer this question, one may point to similarities between medieval Greek apocalypticism and modern-day environmental alarmism. Both paradigms share the anthropocentric emphasis that assigns accountability for natural disasters to human agency and intentionality. That is, they agree in assuming that many natural disasters would not happen without mankind. As one scholar put it: "Contemporary environmentalism is increasingly shaped by scientific claims that human activities are causing ecosystems to collapse and populations of plants and animals to decline, even to extinction." ${ }^{30}$ At least since the 196os, environmental dystopian narratives, in book and film, have reiterated the anthropocentric perspective that climactic destruction is brought about through human agency and that nature merely conveys the consequences of human ecological mismanagement. ${ }^{31}$ The same anthropocentric principle that is prevalent in medieval Greek apocalyptica seems to be operative in contemporary environmental alarmism.

This common feature should not, however, hide the fact that there are a number of differences between the medieval and the modern kind of apocalyptic thinking. For one, they differ with regard to the kind of activism that is needed. Byzantine apocalyptica emphasize moral, pietistic activism that pertains to one's own individual conduct and/or to the communal behavior of the society at large. They do not conceive of ideological or institutional reform. In contrast, contemporary environmentalism endorses not only criticism of

$30 \quad$ B. Taylor, "Environmentalism," in:Encyclopedia of Millennialism and MillennialMovements, ed. R. Landes, New York, NY, 2000, pp. 140-144, at p. 140.

31 For a brief overview of significant publications between the 196os and 199os, see ibid. 
human morality but also calls for political and economic transformation. Another difference lies in the attitude towards religion. Medieval apocalypticism was imbedded in a context of canonized scriptures and religious practices. In contrast, environmental alarmism is grounded in a secular, science-based framework that operates on empirical principles and experimental practices. ${ }^{32}$ Furthermore, Byzantine apocalypses assign voluntary personal agency to men as well as to divine and demonic protagonists. With regard to natural disasters, man was understood to function as the purpose (final cause) and the supernatural powers as the trigger (efficient cause) of the calamities. ${ }^{33}$ In contrast, apocalyptic environmentalism rejects the notions of supernatural causation and of final causes. Instead, it privileges anthropogenic (efficient) causality, which makes it even more anthropocentric than medieval apocalypticism. Moreover, by dismissing final causality (purpose), environmental alarmism does away with the equivocation of natural catastrophes and advocates the unambiguous interpretation of man-made destruction. In contrast, Byzantine prophecies endorse the potential ambivalence of any phenomenal change in the physical world. As has been shown, earthquakes (but also other natural disasters) are axiologically ambiguous events, which need to be properly assessed so as not to misinterpret their ultimate purpose. The sense of intrinsic ambiguity has been lost in transmission from the medieval model to its contemporary counterpart. One may wonder whether the alarmist paradigm of anthropogenic monocausality and interpretative disambiguation provides a more advantageous intellectual strategy to cope with natural disasters.

\section{Acknowledgement}

The paper is a revision of the talk I gave at the graduate conference "Disasters \& Catastrophes: Navigating Periods of Crisis and Transition in Anatolia, the

32 That is not to say that contemporary apocalyptic environmentalism is bereft of religiosity. Regarding its crypto-religious quality, see M. Shellenberger, Apocalypse never: Why environmental alarmism hurts us all, New York, NY, 2020, pp. 260-269.

For a brief discussion of Aristotle's theory of four causes (Physics II.3, Metaphysics v.2), see D. Ross, Aristotle, Sixth edition, London/New York, NY, 1995, pp. 74-77. Regarding the Byzantine reception of Aristotle's theory, see, for instance, Michael Psellos, De omnifaria doctrina, ed. L.G. Westerink, Michael Psellus: De omnifaria doctrina. Critical Text and

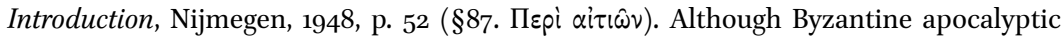
literature does not conceptualize causality, it conveys a rudimentary notion that allows for both efficient and final causes. The chronologically arranged narrative sequence, in which one events triggers the next, manifests efficient causality, while the frequent final clauses (e.g., i $\left.\nu \alpha / i v \alpha \mu \eta^{\prime}\right)$, which assert the ultimate purpose of a given event, convey final causality. 
Mediterranean and the NearEast," organized by the Department of Archaeology and History of Art at Koç University, Istanbul, 25 April 2015. I would like to thank Stefanos Dimitriadis, Panagiotis Theodoropoulos, and Justin Willson for their valuable feedback.

\section{Appendix}

Titles, editions, and approximate dating of the primary sources ${ }^{\mathrm{a}}$

\begin{tabular}{|c|c|c|c|c|}
\hline English title & Latinized title & $\begin{array}{l}\text { Abbreviated } \\
\text { title }\end{array}$ & Edition & $\begin{array}{l}\text { Approx. } \\
\text { date }\end{array}$ \\
\hline $\begin{array}{l}\text { Oracle of } \\
\text { Baalbek }\end{array}$ & $\begin{array}{l}\text { Sibylla Tiburtina } \\
\text { graeca }\end{array}$ & SibTibGr & $\begin{array}{l}\text { P.J. Alexander, The Oracle of } \\
\text { Baalbek. The Tiburtine Sibyl } \\
\text { in Greek Dress, Washington, } \\
\text { DC, } 1967, \text { pp. 9-22 }\end{array}$ & $\mathrm{VI}^{\mathrm{IN}}$ \\
\hline $\begin{array}{l}\text { Apocalypse of } \\
\text { Ps-Methodios }\end{array}$ & $\begin{array}{l}\text { Apocalypsis } \\
\text { Methodii graeca } \\
\text { (redactio prima) }\end{array}$ & ApcMeth & $\begin{array}{l}\text { W.J. Aerts and } \\
\text { G.A.A. Kortekaas, } \\
\text { Die Apokalypse des } \\
\text { Pseudo-Methodius: Die ältesten } \\
\text { griechischen und lateinischen } \\
\text { Übersetzungen, } 2 \text { vols., } \\
\text { Leuven, 1998, I, pp. } 70-198\end{array}$ & VIII IN \\
\hline $\begin{array}{l}\text { Apocalypse of } \\
\text { Daniel }\end{array}$ & Diegesis Danielis & DiegDan & $\begin{array}{l}\text { K. Berger, Die griechische } \\
\text { Daniel-Diegese: Eine } \\
\text { altkirchliche Apokalypse, } \\
\text { Leiden, 1976, pp. 12-23 }\end{array}$ & VIII \\
\hline $\begin{array}{l}\text { Apocryphal } \\
\text { Apocalypse of } \\
\text { John }\end{array}$ & $\begin{array}{l}\text { Apocalypsis } \\
\text { Iohannis apocrypha }\end{array}$ & ApcIoh & $\begin{array}{l}\text { K. von Tischendorf, } \\
\text { Apocalypses apocryphae } \\
\text { Mosis, Esdrae, Pauli, Iohannis, } \\
\text { item Mariae dormitio, Leipzig, } \\
\text { 1866, pp. } 70-94\end{array}$ & VIII/IX \\
\hline $\begin{array}{l}\text { Anonymous } \\
\text { prediction }\end{array}$ & $\begin{array}{l}\text { Anonymi de } \\
\text { rebus Byzantinis } \\
\text { vaticinium }\end{array}$ & AnonymVatic & $\begin{array}{l}\text { A. Vassiliev, Anecdota } \\
\text { graeco-byzantina, pars prior, } \\
\text { Moscow, } 1893 \text {, pp. } 47^{-5} 5^{\circ}\end{array}$ & $\mathrm{IX}^{\mathrm{IN}}$ \\
\hline
\end{tabular}

a For more detail on the sources, see the respective sections in A. Kraft, "An inventory of Medieval Greek apocalyptic sources (c. 500-1500 AD): Naming and dating, editions and manuscripts," Millennium, 15 (2018), pp. 69-143. 
Titles, editions, and approximate dating of the primary sources (cont.)

\begin{tabular}{|c|c|c|c|c|}
\hline English title & Latinized title & $\begin{array}{l}\text { Abbreviated } \\
\text { title }\end{array}$ & Edition & $\begin{array}{l}\text { Approx. } \\
\text { date }\end{array}$ \\
\hline $\begin{array}{l}\text { Ps-Chrysostom } \\
\text { on the Vision of } \\
\text { Daniel }\end{array}$ & $\begin{array}{l}\text { Iohannis } \\
\text { Chrysostomi visio } \\
\text { Danielis }\end{array}$ & Ps-Chrys & $\begin{array}{l}\text { H. Schmoldt, Die Schrift } \\
\text { 'Vom jungen Daniel' und } \\
\text { 'Daniels letzte Vision', Ph.D. } \\
\text { dissertation, Hamburg, 1972, } \\
\text { pp. } 220-236\end{array}$ & $\mathrm{IX}^{\mathrm{MED}}$ \\
\hline $\begin{array}{l}\text { Vision of } \\
\text { Daniel on the } \\
\text { Last Times }\end{array}$ & $\begin{array}{l}\text { Visio Danielis de } \\
\text { tempore novissimo } \\
\text { et de fine mundi }\end{array}$ & VisioDan & $\begin{array}{l}\text { H. Schmoldt, Die Schrift } \\
\text { 'Vom jungen Daniel' und } \\
\text { 'Daniels letzte Vision', Ph.D. } \\
\text { dissertation, Hamburg, 1972, } \\
\text { pp. } 202-218\end{array}$ & $\mathrm{IX}^{2}$ \\
\hline $\begin{array}{l}\text { Apocalypse } \\
\text { of Andrew the } \\
\text { Fool }\end{array}$ & $\begin{array}{l}\text { Apocalypsis } \\
\text { Andreae Sali }\end{array}$ & ApcAndr & $\begin{array}{l}\text { L. Rydén, The Life of St Andrew } \\
\text { the Fool, } 2 \text { vols., Uppsala, 1995, } \\
\text { II, pp. } 25^{8-284}\end{array}$ & $\mathrm{X}^{\mathrm{MED}}$ \\
\hline $\begin{array}{l}\text { Tale of the } \\
\text { True Emperor }\end{array}$ & $\begin{array}{l}\text { Narratio mendici } \\
\text { regis }\end{array}$ & NarrMend & $\begin{array}{l}\text { W.G. Brokkaar et al., The } \\
\text { Oracles of the Most Wise } \\
\text { Emperor Leo \& The Tale } \\
\text { of the True Emperor } \\
\text { (Amstelodamensis graecus } \\
\text { VI E 8), Amsterdam, 2002, } \\
\text { pp. 90-100 }\end{array}$ & $\mathrm{XIII}{ }^{\mathrm{IN}}$ \\
\hline $\begin{array}{l}\text { Apocalypse } \\
\text { of Leo of } \\
\text { Constantinople }\end{array}$ & $\begin{array}{l}\text { Leonis Constantino- } \\
\text { politani de fine } \\
\text { mundi homilia }\end{array}$ & ApcLeonConst & $\begin{array}{l}\text { R. Maisano, L'Apocalisse } \\
\text { apocrifa di Leone di } \\
\text { Costantinopoli, Naples, 1975, } \\
\text { pp. } 65^{-116}\end{array}$ & XIII \\
\hline $\begin{array}{l}\text { Last Vision of } \\
\text { Daniel }\end{array}$ & Ultima visio Danielis & UltVisDan & $\begin{array}{l}\text { H. Schmoldt, Die Schrift } \\
\text { 'Vom jungen Daniel' und } \\
\text { 'Daniels letzte Vision', Ph.D. } \\
\text { dissertation, Hamburg, 1972, } \\
\text { pp. 122-144 }\end{array}$ & $\mathrm{XIII}^{\mathrm{MED}}$ \\
\hline $\begin{array}{l}\text { Visions of } \\
\text { Daniel \& Other } \\
\text { Holy Men }\end{array}$ & $\begin{array}{l}\text { Visiones Danielis } \\
\text { et aliorum } \\
\text { sanctorum } \\
\text { hominum }\end{array}$ & VisDanSanHom & $\begin{array}{l}\text { A. Pertusi, Fine di Bisanzio e } \\
\text { fine del mondo, Rome, } 1988, \\
\text { pp. } 17^{2-201}\end{array}$ & XIII/XIV \\
\hline
\end{tabular}


Titles, editions, and approximate dating of the primary sources (cont.)

\begin{tabular}{|c|c|c|c|c|}
\hline English title & Latinized title & $\begin{array}{l}\text { Abbreviated } \\
\text { title }\end{array}$ & Edition & $\begin{array}{l}\text { Approx } \\
\text { date }\end{array}$ \\
\hline $\begin{array}{l}\text { Prophecyon } \\
\text { the conquest of } \\
\text { Constantinople } \\
\text { from the } \\
\text { Ishmaelites }\end{array}$ & $\begin{array}{l}\text { De expugnatione } \\
\text { Constantinopolis ab } \\
\text { Ismaelitis }\end{array}$ & ExpugCon & $\begin{array}{l}\text { V. Istrin, Откровеніе } \\
\text { Меөодія Патарскаго и } \\
\text { апокрифическія видпнія } \\
\text { Даніила въ византійской и } \\
\text { славяно-русской литерату- } \\
\text { рахъ: изслпдованіе и тек- } \\
\text { стьь, } 2 \text { vols., Мовсоw, 1897, II, } \\
\text { pp. 151-155 }\end{array}$ & $\mathrm{XV}^{\mathrm{MED}}$ \\
\hline $\begin{array}{l}\text { Vision of } \\
\text { Daniel on the } \\
\text { Seven Hills }\end{array}$ & $\begin{array}{l}\text { Visio Danielis de } \\
\text { septem collibus }\end{array}$ & VisDanSepCol & $\begin{array}{l}\text { H. Schmoldt, Die Schrift } \\
\text { 'Vom jungen Daniel' und } \\
\text { 'Daniels letzte Vision', Ph.D. } \\
\text { dissertation, Hamburg, 1972, } \\
\text { pp. 190-198 }\end{array}$ & $\mathrm{XV}^{2}$ \\
\hline
\end{tabular}

